\title{
Wubbels, Theo
}

\section{Educational sciences in the Netherlands: state of affairs and challenges} Erziehungswissenschaft 27 (2016) 52, S. 55-68

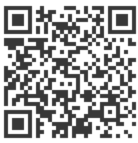

Quellenangabe/ Reference:

Wubbels, Theo: Educational sciences in the Netherlands: state of affairs and challenges - In: Erziehungswissenschaft 27 (2016) 52, S. 55-68 - URN: urn:nbn:de:0111-pedocs-122251 - DOI: $10.25656 / 01: 12225$

https://nbn-resolving.org/urn:nbn:de:0111-pedocs-122251 https://doi.org/10.25656/01:12225

in Kooperation mit / in cooperation with:

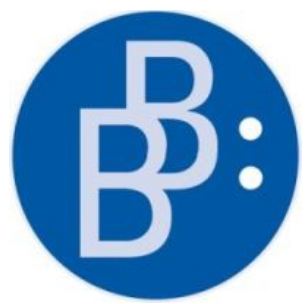

https://www.budrich.de

\section{Nutzungsbedingungen}

Gewährt wird ein nicht exklusives, nicht übertragbares, persönliches und beschränktes Recht auf Nutzung dieses Dokuments. Dieses Dokument ist ausschließlich für den persönlichen, nicht-kommerziellen Gebrauch bestimmt. Die Nutzung stellt keine Übertragung des Eigentumsrechts an diesem Dokument dar und gilt vorbehaltlich der folgenden Einschränkungen: Auf sämtlichen Kopien dieses Dokuments müssen alle Urheberrechtshinweise und sonstigen Hinweise auf gesetzlichen Schutz beibehalten werden. Sie dürfen dieses Dokument nicht in irgendeiner Weise abändern, noch dürfen Sie dieses Dokument für öffentliche oder kommerzielle Zwecke vervielfältigen, öffentlich ausstellen, aufführen, vertreiben oder anderweitig nutzen.

Mit der Verwendung dieses Dokuments erkennen Sie die Nutzungsbedingungen an.

\section{Terms of use}

We grant a non-exclusive, non-transferable, individual and limited right to using this document.

This document is solely intended for your personal, non-commercial use. Use of this document does not include any transfer of property rights and it is conditional to the following limitations: All of the copies of this documents must retain all copyright information and other information regarding legal protection. You are not allowed to alter this document in any way, to copy it for public or commercial purposes, to exhibit the document in public, to perform, distribute or otherwise use the document in public.

By using this particular document, you accept the above-stated conditions of use.

\section{Kontakt / Contact:}

\section{peDOCS}

DIPF | Leibniz-Institut für Bildungsforschung und Bildungsinformation Informationszentrum (IZ) Bildung

E-Mail: pedocs@dipf.de

Internet: www.pedocs.de

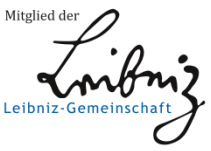




\section{INHALTSVERZEICHNIS}

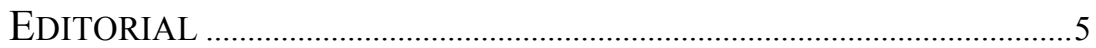

BEITRÄGE ZUM THEMA ,ERZIEHUNGSWISSENSCHAFT IN DEN NACHBARLÄNDERN"

Jean-Luc Patry \& Josef Thonhauser

Erziehungs- und bildungswissenschaftliche Forschung in Österreich .7

Hubert Ertl

Die Erziehungswissenschaft im Vereinigten Königreich: Die erziehungswissenschaftliche Forschungslandschaft im Spiegel der Forschungsevaluation.

Andreas Hadjar

Erziehungswissenschaft(en) in Luxemburg - Eine feste Säule in der noch jungen luxemburgischen Hochschullandschaft

Theo Wubbels

Educational Sciences in the Netherlands: State of Affairs and

Challenges 55

Lucien Criblez

Erziehungswissenschaft in der Schweiz - aktuelle Situation und Entwicklungstendenzen

\section{LAUDATIONES}

\section{Hans-Christoph Koller}

Laudatio für Prof. Dr. Heinz-Elmar Tenorth anlässlich der Verleihung des Ernst-Christian-Trapp-Preises.

Ingrid Miethe, Hannelore Faulstich-Wieland \& Dietrich Benner

Laudatio für Prof. Dr. Sigrid Blömeke anlässlich der Verleihung des

DGfE Forschungspreises

Malte Brinkmann

Laudatio für Dr. Thomas Rucker anlässlich der Verleihung des

Förderpreises der DGfE

Stefanie Hartz \& Ivo Züchner

Laudatio für Dr. Silvia Salchegger anlässlich der Verleihung des

Förderpreises der DGfE 


\section{Marcelo Caruso}

Laudatio für Prof. Dr. Ingrid Gogolin anlässlich der Verleihung der Ehrenmitgliedschaft der DGfE

Marcelo Caruso

Laudatio für Prof. Dr. Klaus-Jürgen Tillmann anlässlich der Verleihung der Ehrenmitgliedschaft der DGfE.

Marcelo Caruso

Laudatio Horst Weishaupt anlässlich der Verleihung der

Ehrenmitgliedschaft der DGfE 105

Autorinnen und Autoren der Laudationes 106

\section{MitTEILUNGEN DES VORSTANDS}

Rechenschaftsbericht über die Vorstandsperiode März 2014 bis März

2016 an die Mitgliederversammlung in Kassel am 15. März 2016

17. Kolloquium „Forschungsberatung“ der DGfE

\section{BERICHTE AUS DEN SEKTIONEN}

Sektion 1 - Historische Bildungsforschung ................................................... 125

Sektion 2 - Allgemeine Erziehungswissenschaft ........................................... 130

Sektion 4 - Empirische Bildungsforschung ................................................ 134

Sektion 8 - Sozialpädagogik und Pädagogik der frühen Kindheit................. 135

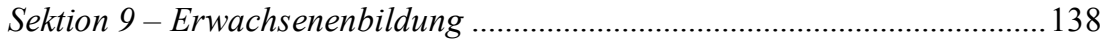

NOTIZEN

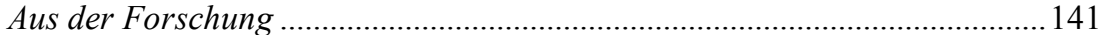

Aus Wissenschaft und Lehre ......................................................................... 147

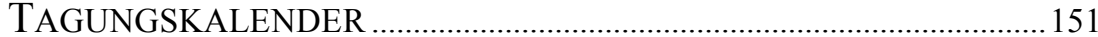

PERSONALIA

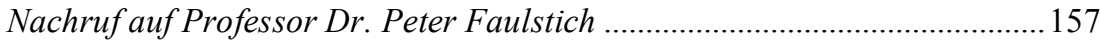

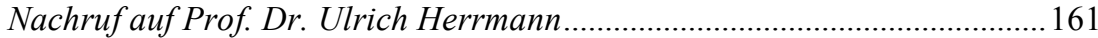

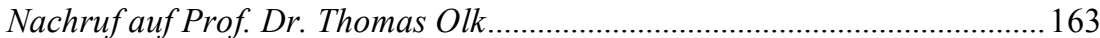




\title{
Educational Sciences in the Netherlands: State of Affairs and Challenges
}

\author{
Theo Wubbels
}

\section{Introduction}

This paper reports on the state of affairs of the „Erziehungswissenschaften“ in the Netherlands. For this description of the educational sciences we primarily rely on a report written in 2014 by a committee that prepared a discipline plan educational sciences (CSO 2014). This report was commissioned by the association of universities in the Netherlands (VSNU, http://www.vsnu.nl/en GB/), the umbrella association of research universities. Such reports regularly are prepared to describe the state of affairs of a discipline and advice on policies for the future development of a discipline. For the educational sciences, the committee was composed of representatives of most universities at the level of university executive boards, faculty deans and department chairs. The participation of executive board members signals the importance they attach to an improvement of education research. This interest seems to originate from a generally perceived lack of impact of education research on practice and policy; an important issue for this paper. Before summarizing the state of affairs in research and teaching in the educational sciences, we define the domain of educational sciences. We conclude with what might be done to strengthen the educational sciences.

\section{The domain}

The CSO (2014) defined the domain of educational sciences as education including teaching, teaching and learning processes and its outcomes, both on the level of the individual and of the society. Educational sciences want to describe, explain and optimize all situations of purposeful learning, that means learning in the case of beforehand specified learning aims. In the end, educational sciences always want to contribute to the improvement of the quality, effectiveness, efficiency, attractiveness and innovation of educational practice and policy.

The committee distinguished three levels in educational processes: the micro level are the cognitive and affective processes and interventions on the individual and classroom level; educational organization, leadership and governance in schools and organizations are the meso level and the macro level includes educational systems and national policies. 
Educational sciences can study both formal and informal teaching and learning situations throughout the life span in all contexts as long as these are organized for learning; so it excludes informal spontaneous learning. The definition of educational sciences includes all school types and also learning in private companies and the educational offerings of cultural and societal organisations, et cetera. Educational sciences are multidisciplinary by nature and include not only the educational sciences per se but also other disciplines such as psychology, sociology, economy, neurosciences and so on, as long as they study education or help improve education.

\section{Research}

This domain was specified further in order to describe in what kind of research the various universities are engaged in. Table 1 shows three main areas of research and more specific themes under these main areas that are studied in Dutch education research.

The table shows that many topics are studied in more than one university. The profiles of the local research programs do not exclude each other. However, the focus in the various universities is different. 
Table 1: Themes in Dutch education research

\begin{tabular}{|c|c|c|c|c|c|c|c|c|c|c|c|c|c|c|c|}
\hline Main area & Theme & $\begin{array}{l}\frac{7}{0} \\
\frac{2}{0} \\
\frac{2}{2} \\
? \\
?\end{array}$ & 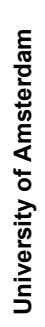 & 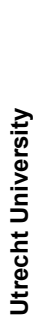 & 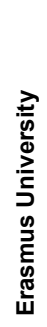 & 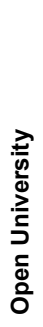 & 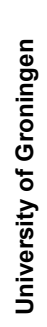 & 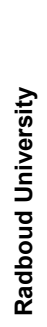 & 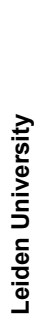 & 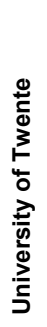 & 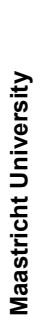 & 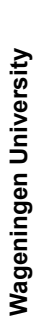 & 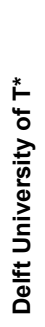 & 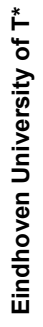 & 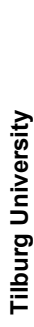 \\
\hline \multirow{8}{*}{$\begin{array}{l}\text { Teaching } \\
\text { and } \\
\text { learning } \\
\text { processes } \\
\text { and } \\
\text { outcomes }\end{array}$} & Teaching and learning & $\mathrm{x}$ & $x$ & $x$ & $x$ & $x$ & $x$ & $x$ & $\mathrm{x}$ & $x$ & $x$ & $x$ & & $x$ & $x$ \\
\hline & $\begin{array}{l}\text { Design of education and } \\
\text { curricula } \\
\text { Curriculum offering }\end{array}$ & $x$ & $x$ & & $x$ & $x$ & & $x$ & $x$ & $x$ & $x$ & & & & \\
\hline & $\begin{array}{l}\text { Differentiation and hand- } \\
\text { ling differences }\end{array}$ & & $x$ & & $x$ & & $x$ & $x$ & $x$ & & $x$ & & & & $x$ \\
\hline & $\begin{array}{l}\text { (Handling) learning disabili- } \\
\text { ties }\end{array}$ & & $x$ & $x$ & & & $x$ & $x$ & $x$ & & & & & & \\
\hline & ICT and education & $x$ & $x$ & $x$ & & $x$ & $x$ & & $x$ & $x$ & $x$ & $x$ & $x$ & $x$ & $x$ \\
\hline & Testing and assessment & $x$ & & & & $x$ & & & $x$ & $x$ & $x$ & $x$ & & & $x$ \\
\hline & $\begin{array}{l}\text { Subject specific aspects of } \\
\text { education }\end{array}$ & $x$ & $x$ & $x$ & & $x$ & $x$ & $x$ & $x$ & $x$ & $x$ & $x$ & $x$ & $x$ & $x$ \\
\hline & $\begin{array}{l}\text { Workplace and informal } \\
\text { learning }\end{array}$ & & & $x$ & & $x$ & & & & $\mathrm{x}$ & $x$ & $x$ & & $x$ & $x$ \\
\hline \multirow{6}{*}{$\begin{array}{l}\text { Organi- } \\
\text { zation and } \\
\text { effective- } \\
\text { ness }\end{array}$} & $\begin{array}{l}\text { Organization, management } \\
\text { governance and leadership }\end{array}$ & & $x$ & & $x$ & & & & & $x$ & & & & & \\
\hline & School effectiveness & & & & $x$ & & $x$ & & & $x$ & $x$ & & & & \\
\hline & $\begin{array}{l}\text { (Success factors in) inno- } \\
\text { vation of education }\end{array}$ & & $x$ & & $x$ & & & & & & $x$ & & & & \\
\hline & Quality assurance & & & & & & & & & & $x$ & & & & \\
\hline & Educational careers & & & & & & $x$ & $\mathrm{x}$ & & & $x$ & & & & \\
\hline & $\begin{array}{l}\text { Teachers, teacher educa- } \\
\text { tion and professionalization }\end{array}$ & $x$ & $x$ & $x$ & $x$ & $x$ & $x$ & $x$ & $x$ & $x$ & $x$ & $x$ & & $x$ & $x$ \\
\hline $\begin{array}{l}\text { Education } \\
\text { and }\end{array}$ & $\begin{array}{l}\text { Societal outcomes and re- } \\
\text { lation with labour market }\end{array}$ & & $x$ & & & & & $x$ & & & $x$ & & & & \\
\hline \multirow[t]{5}{*}{ society } & $\begin{array}{l}\text { Moral and social function } \\
\text { of education }\end{array}$ & $x$ & $x$ & & & & & $x$ & $x$ & & $x$ & & & & \\
\hline & Life long learning & & & & & & & & $x$ & & $x$ & $x$ & & & \\
\hline & $\begin{array}{l}\text { Educational system and } \\
\text { policy }\end{array}$ & & $x$ & & & & & & & & $x$ & & & & \\
\hline & Societal context & & $x$ & $x$ & & & & $x$ & $x$ & & & & & & $x$ \\
\hline & $\begin{array}{l}\text { Inequalities and segrega- } \\
\text { tion }\end{array}$ & & $x$ & $x$ & & & & $x$ & $x$ & & & & & & $x$ \\
\hline
\end{tabular}

\section{Research profiles of the universities}

The largest university in educational sciences (Utrecht University) focuses on the processes in interaction between students, teachers and learning materials (including these processes in teacher education), both in classrooms in schools and in companies. In addition influences on these processes are stud- 
ied and the studies include subject specific approaches in domains such as sciences and medicine. The University of Amsterdam's first point of interest is the connection between processes at the micro level (in classes) and processes at the meso (school) and the macro level (educational system). At the micro level research includes both cognitive and social processes and at the meso level school leadership. In the University of Groningen the programs emphasize an empirical approach towards the study of education, specifically educational effectiveness with a focus on student outcomes. Further professionalization of teachers, learning disabilities and school and youth culture are studied.

The focus of the program at the University of Twente is educational design, specifically with use of technology, support of learning by technology, the influence of all kind of factors on the way schools and classroom operate and in addition the transformations in higher education are a specific topic. Similarly the Open University's programs focus on design of teaching and learning situations for a broad array of educational contexts with the aim to provide effective, efficient and agreeable teaching, including the use of ICT.

In many universities professionalization of teachers is also a topic. The Maastricht University program aims at specific professionals for program design in health education (in particular problem based), for learning in business, and for primary and secondary education, with an emphasis on evidence based practices. A special institute studies the relation between education and the labour market.

The Radboud University approaches education from a learning perspective and the way learning can be optimized in the broad multicultural context of education. Specifically cognitive psychological, psycholinguistic and neural processes and variables influencing these are included.

The research of $V U$ University is heavily cognitive and neuropsychologically oriented. In a theoretical approach, research is concerning optimal learning environments for learning to function in a pluralistic society.

Erasmus University is specialised in problem based learning in higher education, segregation processes in education and the interaction between variables in families and school.

Finally, of the general universities, Leiden University focuses on the fundamental processes involved in learning of both mainstream and disabled students. Mathematics and social competencies get special attention and the competence development is studied all over the life span. In addition learning of teachers is an important topic.

The Universities of Technology (Delft, Eindhoven) focus on research in science education including the role of the teacher's professionalization and the university for agriculture (Wageningen) on competence development in the agricultural sector. The smallest program at Tilburg University studies learning in the languages. 


\section{Trends in topics studied}

From table 1 it is clear that taken together Dutch research focuses more on the micro and meso than on the macro level. Specifically the main area with most research is teaching and learning processes and outcomes, and the least studied one is education and society. On the level of themes the most studied topics are learning and teaching and teachers, teacher education and professionalization. The latter is a result of the fact that the research programs include the research of the university departments that provide teacher training. There is also ample research on design of education and curricula, ICT and education, differentiation and handling differences, testing and assessment and subject specific aspects of education. The least studied themes are topics such as the curriculum offering, educational organization, management, leadership and governance, quality assurance, societal outcomes and relation with the labour market, life long learning and the educational system and policy.

Regarding the educational sectors studied, the emphasis is on primary and general secondary education, leaving higher education and vocational education a bit understudied. Although all main areas are studied the CSO (2014) concluded that several themes should get more attention in future research. These include specific educational sectors such as vocational training, higher education and teaching and learning of adults and the themes excellence, education and ICT, life long learning and the use of big data in education.

When we look at the development over time we can see that many themes have been studied already for a long time, but also some changes in research focus appear. For example, the content of the curriculum offering was a much more studied topic in earlier days. It seems that the turn towards an empirical approach of educational studies and moving away from the study of the history and philosophy of education has taken place in many universities, resulting in less focus in the consideration of what is worth teaching in schools. The attention for evidence based education, professionalization of teachers and outcomes of innovative learning environments is growing and the attention for the educational system is dwindling. Most recently attention for cognitive and brain science is raising and also a beginning of studies using learning analytics can be seen.

\section{Quality}

An international committee has evaluated the quality of the university research programs in 2013 (QANU, 2013). Every five years research is assessed in the national research assessment on a number of indicators. At the moment these are research quality, relevance to society and viability. Education research has still been evaluated under an older system with separate scores for quality and productivity. Evaluation is performed on a five-point scale ranging from 1 (unsatisfactory) to 5 (excellent: the research is world 
leading and researchers are working at the forefront of their field internationally and their research has an important and substantial impact in the field). The score 4 (very good) means that research is considered nationally leading, internationally competitive and makes a significant contribution to the field. All programs were evaluated at nearly all indicators between very good and excellent. The productivity is considered high compared to research in other countries and similar to productivity in other disciplines in the Netherlands such as psychology and sociology. The scholarly impact as a whole is above average compared with other disciplines. In terms of publications for professionals the evaluation differs more between universities: the impact on education varies between universities.

\section{Program size and budgets}

Table 2 shows the size of the research programs in three categories. Some programmes in the third column are very small (less than 5 full time equivalent (fte)) and in the first very large (over $100 \mathrm{fte}$ ). The SCO estimates a total of $610 \mathrm{fte}$ working on education research in universities, including $235 \mathrm{fte}$ $\mathrm{PhD}$ students. In the Netherlands PhD students thus are an important part of the research production force: it is more and more common that their dissertation consists of 4-7 articles in international refereed (preferably ISI) journals and their supervisors usually are co-authors of these articles.

Table 2: Size of research programs in educational sciences per university in full time equivalents (fte)

\begin{tabular}{lll} 
Large (> 50 fte) & Medium (20-50 fte) & Small $(<\mathbf{2 0} \mathbf{f t e})$ \\
\hline Utrecht University & University of Groningen & Eindhoven University of \\
Maastricht University & Wageningen University & Technology \\
Open University & VU University & Tilburg University \\
Leiden university & & Delft University of \\
Radboud University & & Technology \\
University of Twente & & Erasmus University \\
University of Amsterdam &
\end{tabular}

Table 3 presents an overview of the money involved in education research in different institutions. Universities are not the only organizations where education research is undertaken. Other institutions are for example the Central Bureau of Statistics (CBS), the Universities of Applied Sciences (Fachhochschulen), the Netherlands Institute for Social Research (SCP), the Netherlands Bureau for Economic Policy Analysis (CPB) and CITO, the Netherlands Institute for Assessment. The budgets in table 3 are rough estimations and do not include general research institutions such as CBS and CPB. For the latter it is not possible to get a reliable estimate of the budget because education research is interwoven with research on other issues. 
Table 3: Money for educational sciences research

\begin{tabular}{|c|c|c|c|}
\hline Institution & & $\begin{array}{l}\text { Budget } 2014 \\
\text { in } M €\end{array}$ & Comments \\
\hline \multirow[t]{4}{*}{ Universities } & First tier & 38,2 & \\
\hline & $\begin{array}{l}\text { Second tier } \\
\cdot \quad \mathrm{NRO}^{1}\end{array}$ & 18,4 & $\begin{array}{l}\text { Will grow in the coming years with at } \\
\text { least } 3,0 ; \\
\text { Includes e.g., evaluation of the } \\
\text { introduction of new forms of inclusive } \\
\text { education, longitudinal studies of } \\
\text { student careers; international studies } \\
\text { e.g. TIMSS }\end{array}$ \\
\hline & - EU & 2,7 & \\
\hline & Third tier & 6,9 & $\begin{array}{l}\text { Includes mainly funds from the } \\
\text { ministry for policy oriented research }\end{array}$ \\
\hline $\begin{array}{l}\text { Other } \\
\text { (research) } \\
\text { institutions }\end{array}$ & & 16,7 & $\begin{array}{l}\text { Includes e.g., } \\
\text { - grants for teachers to write a } \\
\text { PhD; } \\
\text { - research institute for vocational } \\
\text { education } \\
\text { - research institute for education } \\
\text { and labour market } \\
\text { - research cooperation between } \\
\text { schools and teacher education } \\
\text { - program for evaluation of } \\
\text { evidence based school } \\
\text { improvement }\end{array}$ \\
\hline $\begin{array}{l}\text { Universities } \\
\text { of applied } \\
\text { sciences }\end{array}$ & & 21.6 & $\begin{array}{l}\text { These are } 80 \text { part time staff } \\
\text { members directing a research group }\end{array}$ \\
\hline Sum & & 104,5 & \\
\hline
\end{tabular}

For the universities it appears that about $38 \mathrm{M} €$ is spent from the main budget of the universities (first money tier). An additional amount of about $18 \mathrm{M} €$ is provided mainly to the universities by the Netherlands Initiative for Education Research; part of the Netherlands Organisation for Scientific Research (NWO): the main funding organization for scientific research and about $3 \mathrm{M} €$ comes from the European Union (second money tier). The third money tier includes all other sources for research than the university main budget and $\mathrm{NWO} / \mathrm{EU}$, for example the ministry, city governments, private companies, schools, et cetera. A growing amount of money for research is accounted for in the universities of applied science, already over $21 \mathrm{M} €$. Regarding the universities there is a tendency that the budget in the first tier is decreasing and there is more and more need to acquire money in the second and third tier to keep research running. This is a dangerous situation for the future of education research because the competition is tough. For example in NWO the 
chance for getting funded is only between 5 and $15 \%$. Because also at NWO more and more practice and policy oriented research are preferred the basic, curiosity driven research is under threat.

\section{Teaching programs}

Table 4 shows the undergraduate and graduate programmes offered at the different universities. The technical universities (Eindhoven and Delft), Wageningen University and Tilburg University are missing because they do not offer educational sciences programs.

They do, however, offer teacher education programs and thus there is a connection between their education research and their teaching programs offering. All universities have a specific profile in their program offering, usually connected to the focus of their research programs. 
Table 4: University teaching programs and student numbers

\begin{tabular}{|c|c|c|c|c|c|c|c|}
\hline \multirow[t]{2}{*}{ University } & \multicolumn{2}{|c|}{$\begin{array}{l}\text { Under- } \\
\text { graduate }\end{array}$} & \multicolumn{3}{|c|}{ Graduate one year } & \multicolumn{2}{|c|}{ Graduate two year $^{3}$} \\
\hline & $\begin{array}{l}\text { Full } \\
\text { time }\end{array}$ & $\begin{array}{l}\text { Part } \\
\text { time }^{2}\end{array}$ & Name & $\begin{array}{l}\text { Full } \\
\text { time }\end{array}$ & $\begin{array}{l}\text { Part } \\
\text { time }\end{array}$ & Name & $\begin{array}{l}\text { Full } \\
\text { time }\end{array}$ \\
\hline $\begin{array}{l}\text { Utrecht } \\
\text { University }\end{array}$ & 134 & 33 & $\begin{array}{l}\text { Educational } \\
\text { design and } \\
\text { consultancy }\end{array}$ & 108 & 130 & $\begin{array}{l}\text { Educational } \\
\text { Sciences: } \\
\text { Learning in } \\
\text { Interaction }\end{array}$ & 38 \\
\hline $\begin{array}{l}\text { University of } \\
\text { Twente }\end{array}$ & 64 & 0 & $\begin{array}{l}\text { Educational } \\
\text { Science and } \\
\text { Technology }\end{array}$ & 52 & 31 & & \\
\hline $\begin{array}{l}\text { University of } \\
\text { Amsterdam }\end{array}$ & 49 & 0 & $\begin{array}{l}\text { Educational } \\
\text { Sciences }\end{array}$ & 49 & 8 & $\begin{array}{l}\text { Child } \\
\text { Development } \\
\text { and Education }\end{array}$ & 5 \\
\hline VU University & & & $\begin{array}{l}\text { Teaching and } \\
\text { Learning in } \\
\text { Higher } \\
\text { Education }\end{array}$ & & 22 & & \\
\hline $\begin{array}{l}\text { University of } \\
\text { Groningen }\end{array}$ & & & $\begin{array}{l}\text { Educational } \\
\text { Sciences }\end{array}$ & 99 & 0 & $\begin{array}{l}\text { Human } \\
\text { Behaviour in } \\
\text { Social Context }\end{array}$ & 39 \\
\hline $\begin{array}{l}\text { Maastricht } \\
\text { University }\end{array}$ & & & $\begin{array}{l}\text { Health } \\
\text { Professions } \\
\text { Education }\end{array}$ & & 39 & & \\
\hline & & & $\begin{array}{l}\text { Evidence based } \\
\text { Innovation in } \\
\text { Teaching } \\
\text { Management of } \\
\text { Learning }\end{array}$ & 46 & 72 & & \\
\hline $\begin{array}{l}\text { Leiden } \\
\text { University }\end{array}$ & & & $\begin{array}{l}\text { Education and } \\
\text { Child Studies }\end{array}$ & 40 & & & \\
\hline $\begin{array}{l}\text { Open } \\
\text { University }\end{array}$ & & & $\begin{array}{l}\text { Educational } \\
\text { Sciences }\end{array}$ & & 160 & & \\
\hline $\begin{array}{l}\text { Radboud } \\
\text { University }\end{array}$ & & & $\begin{array}{l}\text { Educational } \\
\text { Sciences }\end{array}$ & 26 & & $\begin{array}{l}\text { Behavioural } \\
\text { Sciences }\end{array}$ & 25 \\
\hline
\end{tabular}

$\begin{array}{llllll}\text { Total } & 247 & 33 & 420 & 442 & 107\end{array}$

${ }^{1}$ Number of students enrolled in a three year program: yearly entrance is about $1 / 3$ of these numbers.

${ }^{2}$ In part time programs the students generally study twice as long.

${ }^{3}$ These are programs for training of researchers and are only offered for full time students.

\section{Undergraduate}

Only three universities offer a specific undergraduate program in educational sciences (Utrecht University, University of Amsterdam and University of Twente) and one of these (University of Twente) is in the process of stopping 
this program. Such a program normally includes 180 ECTS, with a major of about 135 ECTS educational sciences including between 15 and 30 ECTS research methodology and philosophy of education and several optional courses. Further between 30 and 45 ECTS are usually completely free choices for students. Most other general universities, offer in their programs for special education a track aimed at educational sciences. These usually include about 90 ECTS specialisation in educational sciences.

\section{Graduate}

There are 11 one-year graduate programs at what is called the academic master level. These programs prepare students for professions where a university education is needed, for example as policy adviser for among others in the government, cities, or school boards, educational consultants or trainers in companies or organizations, school advisers, et cetera. Then there are four two-year research master programs preparing students for a research career either as a $\mathrm{PhD}$ student in a university or in an education research institution. Of these programs only the one in Utrecht is specifically an educational sciences program and this has grown over the last few years from about 10 to 20 yearly entrants. All others are umbrella programs where students can opt for a specialization in educational sciences and the enrolment in such a specialisation is lower than the number in the table.

In most master programs a clear distinction in the target group of students is visible between the full time and part time enrolments. Where the part time enrolment dominates, the programs are aiming at adult students with previous teaching experience in schools, companies, professional organizations or universities. Such programs for professionals academic aim at deepening and underpinning their practice, usually including a practice oriented research assignment. Programs with mainly full-time students aim at entrants immediately after completion of an undergraduate program in educational sciences or a specialisation in a special education program. Here the theoretical content is more prominent and the research often is more advanced.

\section{PhD training}

For the training of $\mathrm{PhD}$ students in education, nearly all Dutch universities (except Tilburg University) cooperate with each other and with three Flemish universities (Leuven, Antwerp, Ghent) in the Interuniversity Center for Educational Sciences (ICO). All PhD students at these universities who spend a minimum of three days a week on their $\mathrm{PhD}$ are member of ICO if their research plan has been approved by the ICO board. Usually these PhD students are also part of a graduate school in their own university. Such schools usually cover a broad range of disciplines such as all behavioural or all social and behavioural $\mathrm{PhD}$ programs. $\mathrm{PhD}$ students enrol in courses offered by the 
graduate schools in their own university on general topics such as research methodology, teaching methodology and scientific writing. ICO offers courses that are specific for the educational sciences for example on teaching and teacher education, curriculum design, evaluation and assessment, and learning and instruction. $\mathrm{PhD}$ students have to take a minimum of $18 \mathrm{EC}$ in courses and to participate in two yearly conferences in which $\mathrm{PhD}$ students present their research. They get a minimum of 600 hours of supervision during the four years of the $\mathrm{PhD}$ (in case of a full time appointment). All $\mathrm{PhD}$ supervisors have to be staff members of the ICO for which they must have published at least six publications in international journals every five years. The number of members is about 185 university staff and 25 post docs. Every year about $25 \mathrm{PhD}$ students graduate in ICO, whereas outside ICO about the same number graduates. These are for example psychologists studying an educational topic or teachers who do not have sufficient time to participate in ICO. Generally the training seems to work well for the regular PhD students, that means those who have an appointment in a university to work on their PhD. There is, however, an increasing number of other PhD students, for example from other countries with a bursary, or staff members of universities of applied sciences and teachers who want to write a $\mathrm{PhD}$ but do not have the same amount of time to work on it. For these students the ICO course offering is interesting, but for practical reasons the students are often not able to enrol. So there is a need for more differentiated, flexible and perhaps blended forms of courses to adapt to the needs of these students.

\section{Netherlands Initiative for Education Research}

Commissioning the report of the CSO stands in a line of considerable attention of the government for the educational sciences. Such attention is encouraged by the wish of politicians (and many researchers) to make education research help improve education. The recent interest in the role of research in educational innovation started in 2010 when the minister of education established a committee to investigate the quality and impact of education research in the Netherlands. The background of this initiative was the perceived lack of impact of education research on practice and the many educational innovations that were not successful. The committee called its report National plan educational/learning sciences (Commissie Nationaal Plan Toekomst Onderwijswetenschappen 2011) to emphasise that educational science was too limited a description of the field of study that is important for improving the quality of education. The committee produced a list of problems in the educational sciences: 
- A continuity problem: The number of students in the teaching programs in educational sciences and university teacher education was low and this was threatening the viability of these programs.

- An activation problem: knowledge that is available in many disciplines and could be used to improve education wasn't used and part of the reason was that the grants for research were provided along disciplinary lines which hindered multi- and interdisciplinary approaches.

- A fragmentation problem: The education research in the first tier at the universities was fragmented, lacked coherence and there were many small programs.

- Chain failing: The current institutions did not succeed in making the knowledge from educational sciences available for practice and policy.

- A quality problem: Research in the third tier lacked quality control and the money was provided without clear aims and guarantee for methodological rigour.

- Attraction of international journals: Because education researchers are evaluated on their publications in scholarly journals, research lacked connection with practice and policy.

- Under use of education research results: practitioners did not show sufficient interest in research results and the competence to use the results and develop research questions was lagging behind.

As our description of the state of affairs in the educational sciences above shows many of these problems still continue.

The then existing program council for education research of the Netherlands Organization for Scientific Research (NWO), the Netherlands Association for Educational Research and the Interuniversity Center for Educational Sciences (ICO) collaborated to send this committee a proposal to establish a funding organisation that would bring together all money for education research with money for innovations so that these budgets would be granted in connection to each other. The committee endorsed this proposal and incorporated it in its report. As a result the Netherlands Initiative for Education Research (NRO) was established in 2012 (https://www.nro.nl/en/about/). In this organization indeed several sources of research money (but not all, as is clear form table 3) were brought together, but unfortunately no innovation money was granted to this organization.

NRO has three tasks: facilitating the coherency of education research by providing direction at a national level, awarding grants for high quality research, and facilitating knowledge utilisation by improving the links between science and practice. NRO tries to connect research and practice e.g. through the involvement of practitioners and policy makers in the programming of research. It covers all educational sectors: from pre-school to university education, special education, adult education, in-service training and professional 
development; and includes all disciplines related to educational sciences: psychology, pedagogics, sociology, law, economics, et cetera.

The budget of NRO is divided in three parts. The largest part is for practice-oriented research, that means research in which researchers and practitioners collaborate. Smaller amounts are available for fundamental and policy oriented research. This separation in three parts seems to hinder the development of comprehensive research proposals and therefore there are efforts to find ways to integrate the three perspectives. One of the strong points of establishing the NRO is the rigorous evaluation procedure that now is used for government funded research projects. As table 3 shows, unfortunately, still a lot of research budgets are not under the governance of the NRO.

\section{Challenges}

In its conclusion, the CSO (2014) calls education the power engine for society and education research an auxiliary engine. Educational sciences have to provide a body of knowledge for evidence informed approaches in education and have to train educational experts and have to contribute to the professionalization of teachers. The committee concludes that the quality of education research is fine but that it doesn't realize the role of auxiliary engine for education. Both research and teaching in the educational sciences need to be renewed and three tasks for the near future are described.

In research, the committee argues, the overlap between programs in various universities should be diminished and small programs should cooperate more with other programs in order to get a minimum size of $10 \mathrm{fte}$, which is also the minimum size required in the national research evaluation. The plea for collaboration applies specifically for the small programs on subject specific research (Fachdidaktik) and these programs and general education research should collaborate more. A national agenda for research and innovation in education should be developed and all money for education research outside the first tier should be granted via the NRO. The research of universities and universities of applied sciences should be integrated.

Although the quality of the teaching programs is fine, they do not attract sufficient students to make these programs viable. A paradox is that the graduates of the programs easily get jobs, but that this fact doesn't translate into larger enrolments in the programs. The committee suggests making these programs more attractive by introducing more modern topics in the programs such as the use of big data and learning analytics. A faster introduction of new knowledge developments (for example in the neuro sciences) is needed and the connection with the professions these programs prepare students for needs to be improved. Further, collaboration and sharing of personnel between teaching programs is advocated. 
Key for success of the educational sciences, according to the CSO (2014), is a better connection between educational sciences and practice and policy. Therefore renewing research and teaching programs is not sufficient and the committee advocates that research projects are more initiated based on the problems that practitioners and policy makers experience. One practical suggestion for that is building academic workshops where researchers and practitioners meet each other and work together on solving educational problems, doing research, developing curricula, preparing teachers and teacher professionalization. At the moment NRO is selecting consortia of schools, universities and universities of applied sciences to perform a pilot with these workshops.

\section{Conclusion}

The field of educational sciences in the Netherlands is rather dynamic and under continuous interest of policy makers both at the government and university level. From the wish that educational sciences help improve education, educational sciences face many challenges. Meeting these challenges is important for the viability of the educational sciences but need to be undertaken without forgetting that fundamental research is an engine for all educational improvement.

Theo Wubbels, Prof. Dr., ist Hochschullehrer für Education an der Universität Utrecht.

\section{Literatur}

CSO (2014): Sectorplan onderwijswetenschappen (Discipline plan educational eciences). The Hague: VSNU. http://www.vsnu.nl/files/documenten/D omeinen/Onderwijs/Sectorplan_onderwijswetenschappen.pdf [Zugriff: 3 . April 2016].

Commissie Nationaal Plan Toekomst Onderwijswetenschappen (2011): Nationaal plan onderwijs/leerwetenschappen. Committee national plan educational sciences (2010), National plan educational/learning sciences. https://www.nro.nl/wp-content/uploads/2014/02/Nationaal-Plan-Onderwi js-Leerwetenschappen-2011.pdf [Zugriff: 3. April 2016].

QANU (2013): Research Review Pedagogics and Education Science. Utrecht: Quality Assurance Netherlands Universities. http://www.qanu.nl/si tes/default/files/bestanden/files/Research\%20Review\%20Pedagogics\%2 0and\%20Education\%20Science\%202013.pdf [Zugriff: 3. April 2016]. 